\title{
Research on the Issue of the
} Individual Behavior and Social Atmosphere of "Keeping-Up with the Joneses" and Rural Households' Marriage Expenditure: An Analysis Based on Buck's Survey Data of Chinese Farmers during 1929-1933

\author{
Hanlu Wang, Hao Hu, Yi Yu* \\ College of Economics and Management, Nanjing Agricultural University, Nanjing, China \\ Email: *yuyi11@163.com
}

How to cite this paper: Wang, H.L., Hu, H. and Yu, Y. (2019) Research on the Issue of the Individual Behavior and Social Atmosphere of "Keeping-Up with the Joneses" and Rural Households' Marriage Expenditure: An Analysis Based on Buck's Survey Data of Chinese Farmers during 1929-1933. Open Journal of Social Sciences, 7, 217-227.

https://doi.org/10.4236/jss.2019.77020

Received: June 14, 2019

Accepted: July 23, 2019

Published: July 26, 2019

Copyright $\odot 2019$ by author(s) and Scientific Research Publishing Inc. This work is licensed under the Creative Commons Attribution International License (CC BY 4.0).

http://creativecommons.org/licenses/by/4.0/ (c) (i) Open Access

\begin{abstract}
Marriage expenditure behavior is not only an economic behavior, but also with its social meaning, which can be easily affected by mind of rivalry. Based on Buck's survey data of Chinese farmers during 1929-1933, this paper has analyzed the connection between the behavior of "keeping-up with the Joneses" and mind of rivalry, as well as the relationship between individual behavior and social atmosphere of "keeping-up with the Joneses". Through innovatively constructing the measurable index of the behavior of "keeping-up with the Joneses", this paper has also quantitatively analyzed the impact of income gap and credit availability on the atmosphere of "keeping-up with the Joneses", and its effect on pushing up the marriage expenditure. The empirical results indicate that economic factors, such as income gap and credit availability, will have significant influence on the atmosphere of "keeping-up with the Joneses". With large income gap and deficient financing channels, rural households will decrease the degree of their individual behavior of "keeping-up with the Joneses", which will further weaken the whole social atmosphere of "keeping-up with the Joneses"; otherwise, with small income gap and sufficient financing channels, the social atmosphere will be strengthened. At the same time, through forming social pressure, individual mind of rivalry may also be strengthened, pushing up the final marriage expenditure.
\end{abstract}




\section{Keywords}

Marriage Expenditure, Mind of Rivalry, "Keeping-Up with the Joneses" Atmosphere, Income Gap, Credit Availability

\section{Introduction}

Marriage expenditure refers to various forms of investment in the marriage process. It is not only an economic behavior affected by income, but also an important factor of building and maintaining marriage relationship affected by social factors [1]. The mind of rivalry is an important factor affecting marriage expenditure [2], which will push up rural households' marriage expenditure to a higher level under the relatively closed rural communities [3]. The mind of rivalry among rural households will lead to individual behavior of "keeping-up with the Joneses": the stronger the psychological motivation, the stronger the behavior, which means that lower-income groups will refer to the consumption situation of higher-income groups, and in order to catch up with the marriage expenditure of higher-income groups, they would like to exceed their income capacity through advancing or borrowing [4] [5] [6]; the aggregation of individual behavior of "keeping-up with the Joneses" tends to form the social atmosphere of "keeping up with the Joneses", which will further strengthen the individual mind of rivalry through forming social pressures, then pushing up the marriage expenditure.

However, the ability of lower-income groups to catch up with marriage expenditure of higher-income groups in rural area is constrained by the income gap and credit availability. Relevant research suggests that the income gap has an inhibitory effect on consumption [7] [8] that is, with the income gap widening, rural households will continuously adjust their assessment of their ability to catch up with higher-income groups, which will have an inhibitory effect on excessive marriage consumption. At the same time, consumer finance plays a role in promoting consumption: the increasing borrowing will give rural households more confidence to keep up with the Joneses through the increase of temporary wealth, as well as to enhance the possibility of transforming the mind of rivalry to real behavior [9]. Therefore, only the real behavior of "keeping-up with the Joneses" can be observed, which can reflect the individual mind of rivalry. With the popularization of the behavior of "keeping-up with the Joneses", the social atmosphere of "keeping-up with the Joneses" will be formed under social pressure, strengthening the individual mind of rivalry and then pushing up the final marriage expenditure.

In the 1920s and 1930s, the economic conditions of rural society were generally poor, but the phenomenon of high marriage expenditure was prevalent [10], such conflict indicating that the behavior of "keeping-up with the Joneses" was more obvious in terms of marriage expenditure than other consumption ex- 
penditures, and the individual rural households' perception of the atmosphere of "keeping-up with the Joneses" was stronger, increasing the marriage expenditure under this social pressure. Therefore, the rural society in this period is an excellent object of researching the issue of marriage expenditure under the atmosphere of "keeping-up with the Joneses". As Buck's survey data of Chinese famers during 1929-1939 could exactly reflect the production and living conditions of rural households in that period, which has high value of research, this paper has constructed the mechanism about how the mind of rivalry affects the behavior of "keeping-up with the Joneses", the individual behavior contribute to social atmosphere of "keeping-up with the Joneses", the social atmosphere strengthen the individual mind of rivalry, and then affect the marriage expenditure. At the same time, this paper has also analyzed the impact of income gap and credit availability on the atmosphere of "keeping-up with the Joneses", and its effect on pushing up the marriage expenditure.

\section{Quantification of "Keeping-Up with the Joneses" Index}

This paper defines the behavior of "keeping-up with the Joneses" as the process that the lower-income consumers try to catch up with the higher-income consumers' consumption level in order to gain identity and sense of class belonging, which is particularly evident in marriage expenditure, even the lower-income rural households would like to spend approximate or more in marriage.

According to the definition, this paper firstly constructs the index $C_{i}$ to measure individual behavior of "keeping-up with the Joneses", as shown in formula (1):

$$
C_{i}=\frac{B_{i}-B_{i+1}}{A_{i+1}-A_{i}}, i=1,2, \cdots, n-1
$$

$A_{i}$ represents the income of rural household $i$, and $B_{i}$ represents the marriage expenditure of rural household $i$. The rural households in one region are ranked according to their income from highest to lowest, and the income of rural household $i+1$ is above the rural household $i$. When, $C_{i} \geq 0$ it indicates that the marriage expenditure of lower-income rural households surpass the higher-income rural household, showing the individual behavior of "keeping-up with the Joneses", the bigger $C_{i}$, the stronger the behavior; when, $C_{i}<0$ it indicates that the rural household doesn't show obvious behavior, the smaller $C_{i}$, the lower marriage expenditure of the lower-income rural household.

The regional degree of "keeping-up with the Joneses" $C$ is expressed by the mean value of the individual behavior of "keeping-up with the Joneses", as shown in formula (2):

$$
C=\frac{1}{n-1} \sum_{i=1}^{n-1} \frac{B_{i}-B_{i+1}}{A_{i+1}-A_{i}}, i=1,2, \cdots, n-1
$$

When $C \geq 0$, it indicates that the region generally shows the atmosphere of 
"keeping-up with the Joneses", the larger $C$, the higher the regional degree; when $C<0$, the region does not form the obvious atmosphere of "keeping-up with the Joneses", the smaller $C$, the lower the regional degree.

\section{Data Source and Model Construction}

\subsection{Data Source}

The research data comes from Buck's survey data of Chinese farmers during 1929-1933 in Nanjing Agricultural University, involving 16,786 farms in 168 regions of 22 provinces, fully showing the different types of Chinese rural households' production and living conditions in the 1920s and 1930s. At the same time, Buck divided the whole Chinese agricultural area into two major parts, wheat zone and rice zone, with eight specific agricultural regions. According to the research needs, since there are very few samples of rural households with marriage expenditure in Winter Wheat and Sorghum Region, and Sichuan Rice Region, this paper just selected six representative agricultural regions, covering 70 counties, and 3155 rural households with marriage expenditure and complete relevant index data. The basic conditions of the sample are shown in Table 1.

\subsection{Model Construction}

This paper took two steps. Firstly, it explored the influence of economic factors like income gap and credit availability on the atmosphere of "keeping-up with the Joneses", and then analyzed the impact of such atmosphere on the marriage expenditure regionally. Table 2 below has shown variable description and descriptive statistical analysis in following models.

Table 1. Sample basic condition.

\begin{tabular}{|c|c|c|c|c|c|}
\hline Zone & $\begin{array}{l}\text { Agricultural } \\
\text { Region }\end{array}$ & $\begin{array}{l}\text { Main Coverage } \\
\text { Area }\end{array}$ & $\begin{array}{l}\text { Sample } \\
\text { County }\end{array}$ & $\begin{array}{l}\text { Sample } \\
\text { Rural } \\
\text { Households }\end{array}$ & $\begin{array}{l}\text { Average } \\
\text { Marriage } \\
\text { Expenditure } \\
\text { (Unit: Yuan) }\end{array}$ \\
\hline \multirow{2}{*}{$\begin{array}{l}\text { Wheat } \\
\text { Zone }\end{array}$} & $\begin{array}{l}\text { Spring Wheat } \\
\text { Region }\end{array}$ & Northwest Area & 7 & 431 & 91.11 \\
\hline & $\begin{array}{l}\text { Winter Wheat } \\
\text { and Millet Region }\end{array}$ & $\begin{array}{l}\text { North China and } \\
\text { Shanxi Area }\end{array}$ & 15 & 684 & 89.62 \\
\hline \multirow{4}{*}{$\begin{array}{l}\text { Rice } \\
\text { Zone }\end{array}$} & $\begin{array}{l}\text { Yangtze Rice and } \\
\text { Wheat Region }\end{array}$ & $\begin{array}{l}\text { Lower-middle } \\
\text { Reaches of } \\
\text { Yangtze River }\end{array}$ & 14 & 737 & 162.73 \\
\hline & $\begin{array}{l}\text { Rice and Tea } \\
\text { Region }\end{array}$ & East China Area & 18 & 721 & 129.78 \\
\hline & $\begin{array}{l}\text { Twice-Harvest } \\
\text { Rice Region }\end{array}$ & South China Area & 6 & 196 & 416.93 \\
\hline & $\begin{array}{l}\text { Southwest } \\
\text { Rice Region }\end{array}$ & Southwest Area & 10 & 386 & 439.47 \\
\hline
\end{tabular}


Table 2. Variable description and descriptive statistical analysis.

\begin{tabular}{|c|c|c|c|c|c|c|}
\hline Variable & Definition & Description & Mean & $\begin{array}{l}\text { Standard } \\
\text { Deviation }\end{array}$ & Min & Max \\
\hline$W$ & $\begin{array}{l}\text { Marriage } \\
\text { expenditure }\end{array}$ & Unit: yuan & 179.22 & 281.91 & 2 & 4000 \\
\hline$C$ & $\begin{array}{l}\text { Degree of } \\
\text { "keeping-up with } \\
\text { the Joneses" }\end{array}$ & As shown in formula (2) & 0.32 & 7.49 & -23.21 & 27.76 \\
\hline Com & $\begin{array}{l}\text { Atmosphere of } \\
\text { "keeping-up with } \\
\text { the Joneses" }\end{array}$ & $\begin{array}{l}\text { When } C<0, \quad \text { Com }=0 ; \\
\text { When } C \geq 0, \quad \text { Com }=1\end{array}$ & 0.57 & 0.50 & 0 & 1 \\
\hline Long & $\begin{array}{l}\text { Long-term } \\
\text { income level }\end{array}$ & $\begin{array}{l}\text { Agricultural land area; } \\
\text { Unit: hectare }\end{array}$ & 1.99 & 6.49 & 0.06 & 274.14 \\
\hline Gap & Income gap & $\begin{array}{l}\text { The standard deviation } \\
\text { of agricultural land area; } \\
\text { Unit: hectare }\end{array}$ & 1.77 & 5.33 & 0.22 & 44.91 \\
\hline Short & $\begin{array}{l}\text { Short-term } \\
\text { income level }\end{array}$ & $\begin{array}{l}\text { Per capita production; } \\
\text { Unit: kilogram per grain/ } \\
\text { person }\end{array}$ & 400.30 & 362.22 & 0 & 3854.24 \\
\hline Credit & Credit availability & $\begin{array}{l}\text { Percentage of rural } \\
\text { households with borrowing }\end{array}$ & 37.52 & 21.48 & 4.95 & 96 \\
\hline Borrow & $\begin{array}{l}\text { Borrowing for } \\
\text { non-production }\end{array}$ & Unit: Silver dollar & 76.23 & 321.73 & 0 & 9195 \\
\hline Labor & $\begin{array}{l}\text { Number of } \\
\text { laborers }\end{array}$ & Unit: person & 4.03 & 2.47 & 0 & 24 \\
\hline$D_{\text {dong }}$ & $\begin{array}{l}\text { Winter wheat } \\
\text { and millet region }\end{array}$ & $\begin{array}{l}\text { Whether happened in this } \\
\text { region: no }=0 \text {, yes }=1\end{array}$ & 0.22 & 0.41 & 0 & 1 \\
\hline$D_{\text {yang }}$ & $\begin{array}{l}\text { Yangtze rice and } \\
\text { wheat region }\end{array}$ & $\begin{array}{l}\text { Whether happened in this } \\
\text { region: no }=0 \text {, yes }=1\end{array}$ & 0.23 & 0.42 & 0 & 1 \\
\hline$D_{\text {cha }}$ & $\begin{array}{l}\text { Rice and tea } \\
\text { region }\end{array}$ & $\begin{array}{l}\text { Whether happened in this } \\
\text { region: no }=0 \text {, yes }=1\end{array}$ & 0.23 & 0.42 & 0 & 1 \\
\hline$D_{\text {liang }}$ & $\begin{array}{l}\text { Twice-harvest rice } \\
\text { region }\end{array}$ & $\begin{array}{l}\text { Whether happened in this } \\
\text { region: no }=0 \text {, yes }=1\end{array}$ & 0.06 & 0.24 & 0 & 1 \\
\hline$D_{x i}$ & $\begin{array}{l}\text { Southwest rice } \\
\text { region }\end{array}$ & $\begin{array}{l}\text { Whether happened in this } \\
\text { region: no }=0 \text {, yes }=1\end{array}$ & 0.12 & 0.33 & 0 & 1 \\
\hline
\end{tabular}

\subsubsection{The Influence Model of Economic Factors on the Atmosphere of} "Keeping-Up with the Joneses"

To analyze the influence of income gap and credit availability on the atmosphere of "keeping-up with the Joneses", this paper established two kinds of regression models based on the calculation of the regional degree of "keeping-up with the Joneses". In formula (3) of a linear regression model, the explained variable is the county degree of "keeping-up with the Joneses" in six agricultural regions, the explanatory variables are the income gap and credit availability of each county, and the control variables are regional dummy variables; formula (4) keeps the explanatory variables, but changes the explained variable as the existence of the atmosphere of "keeping-up with the Joneses" in each county, which 
is a binary variable, constructing a binary logistic regression model by using the maximum likelihood estimation method.

$$
\begin{gathered}
C=\alpha_{1}+\beta_{1} \text { Gap }+\beta_{2} \text { Credit }+\gamma_{1} D+\varepsilon_{1} \\
C o m=\ln \frac{p}{1-p}=\alpha_{2}+\beta_{3} \text { Gap }+\beta_{4} \text { Credit }+\gamma_{2} D+\varepsilon_{2}
\end{gathered}
$$

$C$ represents the county degree of "keeping-up with the Joneses", which is expressed by the mean value of the individual behavior of "keeping-up with the Joneses" (as shown in formula (2)); Com represents the county atmosphere of "keeping-up with the Joneses", when $C \geq 0, C o m=1$, meaning that the county exists obvious atmosphere of "keeping-up with the Joneses", otherwise, when $C<0, C o m=0$, meaning that the county doesn't exist obvious atmosphere; Gap represents the income gap, showing the standard deviation of the agricultural land area of the rural households in each county ${ }^{1}$; Credit represents the credit availability, showing the borrowing proportion of rural households in each county ${ }^{2} ; D$ represents the regional dummy variable; $p$ represents the probability of the existence of the atmosphere of "keeping-up with the Joneses" $(C o m=1)$, while $1-p$ represents the probability of no such atmosphere $(\mathrm{Com}=0)$.

\subsubsection{The Influence Model of the Atmosphere of Keeping-Up with the Joneses" on the Marriage Expenditure}

In order to further analyze the impact of the atmosphere of "keeping-up with the Joneses" on the marriage expenditure, this paper established a regression model, which took the logarithm of the marriage expenditure in each sample county of the six agricultural regions as the explanatory variable, whether the county had the atmosphere of "keeping-up with the Joneses" as the explanatory variable, as well as the logarithm of the long-term and short-term income level, the number of laborers, and the number of non-production borrowings as control variables, as shown in formula (5).

$$
\log W=\alpha_{3}+\beta_{5} \operatorname{Com}+\sum \lambda_{j} X_{j}+\varepsilon_{3}
$$

$W$ represents the marriage expenditure, Com represents the atmosphere of "keeping-up with the Joneses", $X$ represent the control variables. Specific variables are described as following:

1) Long-term and Short-term Income Level

a) Long-term and short-term income level. Since Buck's data didn't include the specific income information of the farmers, this paper selects the alternative indicators within the available data as much as possible, and finally chooses the

${ }^{1}$ The agricultural land area is the proxy variable of the long-term income level of rural households, which will be explained in formula (5); the standard deviation reflects the degree of deviation of the income of rural households in the county, and the larger the standard deviation, the larger the income gap.

${ }^{2}$ This paper also realized that there could be a self-selection problem when using actual borrowing proportion to represent the credit availability, but limited to data availability, this can only be done in this way. 
"agricultural land area" to represent the long-term income level of the rural households. In Buck's survey, the agricultural land area index can reflect the general income level of farmers at that time as agricultural income was the main source of income, can also reflect the level of household assets represented by fixed assets such as farmhouses and houses which could be used as a way for farmers to evaluate their long-term income. At the same time, as marriage expenditure is an infrequent "one-time expenditure", farmers usually tend to achieve it through long-term accumulation, therefore, marriage expenditure depends more on the long-term income level represented by the agricultural land area.

This paper uses "per capita production" to represent the short-term income level ${ }^{4}$. Crop yield can reflect the income status of farmers in the current period to a certain extent, which can be used to measure the short-term income level of farmers, and the per capita production index is more convenient for comparison between farmers with different family sizes.

b) The ability of borrowing and repayment. This paper chooses "borrowing for non-production use" to measure the ability of borrowing and "the number of laborers" to measure the ability of repayment. Firstly, the borrowing for non-production use $\mathrm{s}^{5}$ could reflect the borrowing ability of rural households on the marriage expenditure to a certain extent, the higher the amount of borrowing, the more likely to increase the marriage expenditure; then, because of the fact that at that time the agriculture operation mainly relied on laborers, the more family labor force, the more likely to give confidence for rural households to repay.

\section{Empirical Test}

\subsection{The Influence of Economic Factors on the Atmosphere of "Keeping-Up with the Joneses"}

The influence of economic factors such as income gap and credit availability on the degree and atmosphere of "keeping-up with the Joneses" is shown in Table 3. In Model 1, the income gap is significant under the $1 \%$ significant level, and in Model 2, the income gap and credit availability are significant under the $10 \%$ and $1 \%$ significant levels respectively, which can be explained to some extent that economic factors have a significant impact on the degree and atmosphere of "keeping-up with the Joneses": with the income gap widening by one unit, the degree and the atmosphere of "keeping-up with the Joneses" will decrease by

${ }^{3}$ The agricultural land area includes farmhouse area, cultivated area and so on, and the paper unitizes the unit of the agricultural land area into "hectare".

${ }^{4}$ In order to facilitate the comparison between regions, this paper refers to Buck's method of calculating "every number of grains per artificial number" in Land Utilization in China and converts the unit of crop yields into "kilogram per grain".

${ }^{5}$ Buck: Land Utilization in China, translated by Qiming Qiao, Shanghai: The Commercial Press, 1937, page 669: "Borrowings for non-production use are mostly consumed by special ceremonies such as wedding, funeral and birthday." 
Table 3. the influence of economic factors on the degree and atmosphere of "keeping-up with the Joneses".

\begin{tabular}{llll}
\hline $\begin{array}{l}\text { Model } 1 \text { the degree of } \\
\text { "keeping-up with the Joneses" }\end{array}$ & \multicolumn{2}{l}{$\begin{array}{l}\text { Model 2 the atmosphere of } \\
\text { "keeping-up with the Joneses" }\end{array}$} \\
\hline Variable & Coefficient & Variable & Coefficient \\
\hline Gap & $-5.41^{* * *}(-30.31)$ & Gap & $-0.91^{*}(-1.83)$ \\
Credit & $0.07(1.33)$ & Credit & $0.06^{* * *}(2.96)$ \\
$D_{\text {dong }}$ & $-3.66(-0.99)$ & $D_{\text {dong }}$ & $-0.50(-0.31)$ \\
$D_{\text {yang }}$ & $-9.03^{* *}(-2.51)$ & $D_{\text {yang }}$ & $-1.08(-0.60)$ \\
$D_{\text {cha }}$ & $-9.82^{* * *}(-2.82)$ & $D_{\text {cha }}$ & $-3.13^{*}(-1.70)$ \\
$D_{\text {liang }}$ & $-7.01(-1.59)$ & $D_{\text {liang }}$ & $-0.69(-0.34)$ \\
$D_{x i}$ & $-9.11^{* *}(-2.07)$ & $D_{x i}$ & $-0.98(-0.49)$ \\
F-test & & LR-test & \\
Statistical value & 138.60 & Statistical value & 24.73 \\
P-value & 0.00 & P-value & 0.00 \\
$\mathrm{R}^{2}$ & 0.94 & Pseudo-R & 0.26 \\
\hline
\end{tabular}

Notes: ${ }^{* *},{ }^{* *}$ and ${ }^{\star}$ represent that the $\mathrm{t}$-value and $\mathrm{z}$-value are significant under the significant levels of $1 \%$, $5 \%$, and $10 \%$ respectively. In model 1 , the values within the brackets are $t$ statistic values, and in model 2 , the values within the brackets are $\mathrm{z}$ statistic values. has the value of the $t$ statistic in bracket parentheses, and the model 2 has the value of the $\mathrm{z}$ statistic in parentheses.

5.41 and 0.91 units separately; with the credit availability increasing by one unit, the degree and the atmosphere of "keeping-up with the Joneses" will enhance by 0.07 and 0.06 units separately. Therefore, with the expansion of the income gap in rural society, rural households will decrease the degree of their individual behavior of "keeping-up with the Joneses", which will further weaken the regional atmosphere of "keeping-up with the Joneses"; while with the increase of credit availability, rural households will enhance the degree of their individual behavior of "keeping-up with the Joneses", which will further strengthen the regional atmosphere of "keeping-up with the Joneses".

Therefore, it could be concluded that with small income gap and high credit availability, rural households will increase their confidence of catching up with the marriage expenditure of higher-income rural households, thereby enhancing the final degree of "keeping-up with the Joneses"; otherwise, with large income gap and low credit availability, even they have the mind of rivalry, the degree of "keeping-up with the Joneses" will be weaken because of the difficulty of catching up with "target" rural households.

\subsection{The Influence of the Atmosphere of "Keeping-Up with the Joneses" on the Marriage Expenditure}

The influence of the atmosphere of "keeping-up with the Joneses" on the marriage expenditure is shown in Table 4. Overall, the key variable the atmosphere of "keeping-up with the Joneses" is significant under the significant level of $1 \%$, 
Table 4. The influence of the atmosphere of "keeping-up with the Joneses" on the marriage expenditure.

\begin{tabular}{|c|c|c|c|c|c|c|c|}
\hline Variable & $\begin{array}{l}\text { Six } \\
\text { Agricultural } \\
\text { Regions }\end{array}$ & $\begin{array}{l}\text { Spring } \\
\text { Wheat } \\
\text { Region }\end{array}$ & $\begin{array}{l}\text { Winter } \\
\text { Wheat } \\
\text { and Millet } \\
\text { Region }\end{array}$ & $\begin{array}{l}\text { Yangtze } \\
\text { Rice and } \\
\text { Wheat } \\
\text { Region }\end{array}$ & $\begin{array}{l}\text { Rice } \\
\text { and Tea } \\
\text { Region }\end{array}$ & $\begin{array}{l}\text { Twice-Harveste } \\
\text { d Rice } \\
\text { Region }\end{array}$ & $\begin{array}{l}\text { Southwest } \\
\text { Rice } \\
\text { Region }\end{array}$ \\
\hline Com & $0.19^{* * *}(5.26)$ & $\begin{array}{l}0.01 \\
(1.11)\end{array}$ & $\begin{array}{l}0.20^{* * *} \\
(2.97)\end{array}$ & $\begin{array}{l}0.66^{* * *} \\
(9.30)\end{array}$ & $\begin{array}{l}0.22^{* * *} \\
(3.29)\end{array}$ & $\begin{array}{l}0.65^{* * *} \\
(6.49)\end{array}$ & $\begin{array}{l}0.13 \\
(1.00)\end{array}$ \\
\hline Long & $\begin{array}{l}0.04^{*} \\
(1.70)\end{array}$ & $\begin{array}{l}0.12^{* *} \\
(2.49)\end{array}$ & $\begin{array}{l}0.19^{* * *} \\
(2.80)\end{array}$ & $\begin{array}{l}0.01 \\
(0.23)\end{array}$ & $\begin{array}{l}0.07^{* *} \\
(2.09)\end{array}$ & $\begin{array}{l}0.48^{* * *} \\
(5.13)\end{array}$ & $\begin{array}{l}1.07^{* * *} \\
(11.83)\end{array}$ \\
\hline Short & $\begin{array}{l}0.32^{* * *} \\
(16.59)\end{array}$ & $\begin{array}{l}0.18^{* * *} \\
(3.55)\end{array}$ & $\begin{array}{l}0.04 \\
(0.74)\end{array}$ & $\begin{array}{l}0.21^{* * *} \\
(5.50)\end{array}$ & $\begin{array}{l}0.22^{* * *} \\
(4.49)\end{array}$ & $\begin{array}{l}0.34^{* * *} \\
(3.29)\end{array}$ & $\begin{array}{l}0.06 \\
(0.81)\end{array}$ \\
\hline Labor & $\begin{array}{l}0.06^{* * *} \\
(8.21)\end{array}$ & $\begin{array}{l}0.03^{*} \\
(1.93)\end{array}$ & $\begin{array}{l}0.01 \\
(0.42)\end{array}$ & $\begin{array}{l}0.01 \\
(0.62)\end{array}$ & $\begin{array}{l}0.06^{* * *} \\
(4.21)\end{array}$ & $\begin{array}{l}0.06^{* * *} \\
(3.01)\end{array}$ & $\begin{array}{l}0.01 \\
(0.44)\end{array}$ \\
\hline Borrow & $\begin{array}{l}0.00^{* * *} \\
(5.72)\end{array}$ & $\begin{array}{l}0.00^{* * *} \\
(2.61)\end{array}$ & $\begin{array}{l}0.00 \\
(1.09)\end{array}$ & $\begin{array}{l}0.00 \\
(1.40)\end{array}$ & $\begin{array}{l}0.00 \\
(1.55)\end{array}$ & $\begin{array}{l}0.00 \\
(0.07)\end{array}$ & $\begin{array}{l}0.00^{*} \\
(1.73)\end{array}$ \\
\hline \multicolumn{8}{|l|}{ F-test } \\
\hline $\begin{array}{l}\text { Statistical } \\
\text { Value }\end{array}$ & 86.73 & 14.42 & 4.95 & 29.25 & 15.93 & 22.16 & 42.96 \\
\hline P-value & 0.00 & 0.00 & 0.00 & 0.00 & 0.00 & 0.00 & 0.00 \\
\hline $\mathrm{R}^{2}$ & 0.12 & 0.15 & 0.14 & 0.17 & 0.11 & 0.37 & 0.36 \\
\hline
\end{tabular}

Notes: ${ }^{* *},{ }^{* *}$ and ${ }^{*}$ represent that the $\mathrm{t}$-value and $\mathrm{z}$-value are significant under the significant levels of $1 \%$, $5 \%$, and $10 \%$ respectively; the values within the brackets are $t$ statistic values.

which means that the atmosphere will have a positive impact on the marriage expenditure, the stronger the atmosphere, the more marriage expenditure. The result is similar to some related qualitative researches, such as Chen Sirong and Wang Liye both emphasized the influence of such atmosphere on rural marriage expenditure through the field research in some rural areas [2] [3]. But different from those previous studies, this paper has established the connection between individual behavior and social atmosphere of "keeping-up with the Joneses". The social atmosphere of "keeping-up with the Joneses" will push up the marriage expenditure, and the increase of individual marriage expenditure will also further strengthen the social atmosphere, leading to a vicious circle.

Other control variables also have a significant influence on marriage expenditure. The income expectation represented by long-term income level and the income fluctuation represented by short-term income level together have impact on marriage expenditure. When the income level increases, the marriage expenditure will also increase; the borrowing for non-production use could provide a guarantee for rural households to achieve basic marriage expenditure, the higher the borrowing amount, the more likely for them to increase the marriage expenditure; the number of laborers represents the repayment ability of rural households, the more laborers, the more likely to increase current marriage expenditure.

From the specific perspective of six agricultural regions, in addition to the 
Spring Wheat Region and Southwest Rice Region, in other four agricultural regions, the atmosphere of "keeping-up with the Joneses" have a significant influence on marriage expenditure. It could be explained that because Spring Wheat Region's consumption expenditure is largely depended by the regional economic development, compared with the atmosphere of "keeping-up with the Joneses", economic factors will have more significant influence; Southwest Rice Region has more open social cultural because of better natural conditions, so the mind of rivalry has less impact on rural households, leading to weaker atmosphere of "keeping-up with the Joneses". At the same time, each agricultural region is affected by economic factors such as income, labor, borrowing and credit.

\section{Conclusions}

Based on Buck's survey data of Chinese farmers during 1929-1933, this paper has analyzed the connection between the behavior of "keeping-up with the Joneses" and mind of rivalry, as well as the relationship between individual behavior and social atmosphere of "keeping-up with the Joneses", and quantitatively analyzed the impact of income gap and credit availability on the atmosphere of "keeping-up with the Joneses", and its effect on pushing up the marriage expenditure. The empirical results indicate that economic factors like income gap and credit availability will have significant influence on the atmosphere of "keeping-up with the Joneses". With large income gap and deficient financing channels, rural households will decrease the degree of their individual behavior of "keeping-up with the Joneses", which will further weaken the whole social atmosphere of "keeping-up with the Joneses"; otherwise the social atmosphere will be strengthened, and through forming social pressure, individual mind of rivalry may also be strengthened, pushing up the final marriage expenditure. However, due to the limitations of data, some important indicators such as income in this paper can only be replaced by relevant variables, so the major purpose of this paper is to provide a new method of measuring the atmosphere of "keeping-up with the Joneses" for subsequent researches.

Nowadays, rural society still shows the characteristic of high marriage expenditure, and the atmosphere of "keeping-up with the Joneses" is still an important part of social and cultural factors, which is not beneficial for the construction of rural custom civilization and the modernization of rural society. Therefore, this paper has put forward the following suggestions: 1) Accelerate rural economic construction, improve the living standards of farmers, change the economic and social status of farmers' self-cognition, improve their sense of self-identity and satisfaction, and finally reduce the possibility of the mind of rivalry; 2) Strengthen rural cultural construction, enrich rural cultural life, improve farmers' cultural quality, then gradually help them get rid of the traditional marriage consumption concepts, and develop a scientific and reasonable consumption concept; 3 ) Strengthen and improve the construction of relevant laws and regulations to effectively guide and intervene in the unhealthy atmosphere 
of "keeping-up with the Joneses" in rural areas, forming a diligent marriage atmosphere.

\section{Funding}

Key research project supported by National Natural Science Foundation "Research on National Policy Support System for Agricultural Development in the New Era" (71333008), and "Research on the Impact of Reserve Regulation on Pork Price Fluctuation" (71403123).

\section{Conflicts of Interest}

The authors declare no conflicts of interest regarding the publication of this paper.

\section{References}

[1] Yang, Y. (2012) A Literature Review on the Study of Marriage Payment Change. Reform \& Opening, No. 14, 184-186.

[2] Chen, S. (2011) Sociological Analysis of Marriage High Consumption-Based on Case Study of Jinjiang C Town. Master's Thesis of Zhejiang Normal University, Hangzhou.

[3] Wang, L. (2009) A Study on Farmers in Underdeveloped Regions of Marriage Research Expenses-Y County D Village as an Example. Master's Thesis of Northwest Normal University, Changchun.

[4] Ge, Y. (1988) Analysis of the Behavior of Comparison in Consumption. Academic Forum, No. 4, 44-45.

[5] Liu, J. and Liu, L. (2006) The Theory and Empirical Analysis of Irrational Consumption Behavior. Consumer Economics, No. 1, 85-88.

[6] Lu, X. (2014) A Survey of Rural Comparison from the Perspective of Social Comparative Theory-10 Villages in 3 Cities of Shandong Province as an Example. China Rural Survey, No. 3, 65-72.

[7] Li, J. (2003) Quantitative Analysis of the Influence of Income Gap on Consumer Demand. The Journal of Quantitative \& Technical Economics, No. 9, 5-11.

[8] Lou, F. and Li, X. (2009) Dynamic Empirical Analysis of Consumption Demand of Chinese Urban Residents. Social Sciences in China, No. 3, 109-115.

[9] Han, L. and Du, C. (2012) The Regional and Urban-Rural Differences of Income Gap, Credit Level and Household Consumption. Economic Research Journal, No. S1, 15-27.

[10] Gao, S. (1999) The Analysis of the Rule of Rural Marriage Expenditure in the Republic China Period. Social Science Front, No. 5, 194-199. 